\title{
Influence of Panchagavya foliar spray on the growth attributes and yield of baby corn (Zea mays) cv. COBC 1
}

\author{
Vimalendran Loganathan* and K. Wahab \\ (Tamil Nadu), INDIA \\ *Corresponding author. E-mail: Vimal.tnau@gmail.com \\ Received: May 04, 2014 Revised received: August 12, 2014 ; Accepted: September 27, 2014
}

Department of Agronomy, Faculty of Agriculture, Annamalai University, Annamalai Nagar - 608 002, Chidambaram

\begin{abstract}
Field experiments were conducted at experimental farm, Faculty of Agriculture, Annamalai University, Chidambaram during July to September (2008) and January to March (2009) in two seasons to study the effect of foliar spray of Panchagavya on the growth and yield of Baby corn cv. COBC 1 . The experiments were laid out in Randomized Block Design with fourteen treatments and replicated thrice. The treatments included foliar spray and inorganic nutrient application at various stages of baby corn. The results revealed that application of $100 \%$ recommended dose of fertilizers (RDF) $\left[\mathrm{N}_{150}: \mathrm{P}_{60}\left(\mathrm{P}_{2} \mathrm{O}_{5}\right): \mathrm{K}_{40}\left(\mathrm{~K}_{2} \mathrm{O}\right)\right]$ and 4 sprays $(15,25,35$ and $45 \mathrm{DAS})$ of $3 \%$ Panchagavya recorded the highest growth attributes and yield of fresh Baby corn and this was followed by application of recommended dose of fertilizers (100\%) along with 3 sprays (15, 25 and 35 DAS) of $3 \%$ panchagavya during both the seasons. The least growth and yield parameter were recorded in 3 sprays of $4 \%$ Panchagavya without use of inorganic fertilizers. The increase in growth and yield of baby corn was mainly attributed by greater availability of nutrients through soil application (100 \% RDF) and foliar spray of panchagavya at various stages of crop growth.
\end{abstract}

Keywords: Baby corn, Growth attributes, Panchagavya, Yield

\section{INTRODUCTION}

Baby corn (Zea mays L.) is young corn and rich in nutrients especially in phosphorus content ( $86 \mathrm{mg} 100$ $\mathrm{g}^{-1}$ edible portion) in comparison to other vegetables (21 to $57 \mathrm{mg} 100 \mathrm{~g} \mathrm{~g}^{-1}$ ), attractive low calorie vegetable having high fiber content with cholesterol (Rai et al., 2004). Besides nutritive value, as it is harvested within 5 to 7 days of tassel emergence and the young cob is wrapped up tightly with husk and protected from chemicals. It is sweet flavor and crisp nature contributes to its increasing attractiveness making it an indispensable ingredient in many fancy dishes today. With the increasing concern for health, people have turned towards quality food in place of bulky items. Baby corn has main place as a safe and quality vegetable. Baby corn by products such as tassel, young stalk and green fodder provide delicious feed for cattle (Thavaprakaash et al., 2005). Baby corn requires a regulated and assured supply of nutrients throughout its growing right from seedling stage to maturity stage. Along with inorganic nutrients combination of foliar nutrients improves the yield and quality of fresh baby corn. Nitrogen, phosphorus and potassium are the key nutrients which greatly influence the yield of crops (Auti et al., 1999). The panchagavya is an eco-friendly organic preparation made from cow products. These liquid organic solutions are prepared from cow dung, urine, milk, curd, ghee, legume flour and jaggary. Panchagavya is a foliar nutrition prepared by organic growers of Tamil Nadu as an indigenous material and is used widely for agricultural crops (Natarajan, 2002). Research on foliar application of Panchagavya along with inorganic fertilizer is limited. Keeping these in view, field investigations were carried out to study the influence of inorganic fertilizer combination with Panchagavya foliar spray on the growth attributes and yield of baby corn.

\section{MATERIALS AND METHODS}

Site location and soil nutrient status: The field experiments were carried out during July to September (2008) and January to March (2009) in two seasons to study the effect of foliar spray of Panchagavya on the growth attributes and yield of baby corn cv. COBC 1 at experimental farm, Department of Agronomy, Faculty of Agriculture, Annamalai University, Annamalai Nagar, Chidambaram. The experimental farm is geographically located at $11^{\circ} 24^{\prime} \mathrm{N}$ latitude, $79^{\circ}$ $44^{\prime}$ 'E longitude and $+5.79 \mathrm{~m}$ above mean sea level. The experimental fields were clay loam and the soil fertility status contained available nitrogen $\left(258.5,253.5 \mathrm{Kg} \mathrm{ha}^{-1}\right)$, available phosphorus $\left(17.3,16.8 \mathrm{Kg} \mathrm{ha}^{-1}\right)$ and available potassium (278.2, 282.3 $\mathrm{Kg} \mathrm{ha}^{-1}$ ) during 2008 and 2009, respectively. The organic carbon content was ISSN : 0974-9411 (Print), 2231-5209 (Online) All Rights Reserved (C) Applied and Natural Science Foundation www.ansfoundation.org 
from $0.34-0.38$ per cent.

Weather parameters: The weekly mean maximum and minimum temperatures were 22.6 to $34.26{ }^{\circ} \mathrm{C}$ and 21.34 to $30.88{ }^{\circ} \mathrm{C}$, during 2008 and 2009 , respectively. The mean relative humidity is 87 per cent. The mean annual rainfall is $1500 \mathrm{~mm}$ of which $1000 \mathrm{~mm}$ is received during North-East monsoon (October to December) and $400 \mathrm{~mm}$ during South-West monsoon (June to September) and 100 $\mathrm{mm}$ as summer showers (January to May).

Experimental details: The experiments were laid out in randomized block design with three replications and fourteen treatments. The following treatments were included in the study, $\mathrm{T}_{1}$-recommended dose of fertilizers (RDF) (150: 60: $40 \mathrm{Kg}$ NPK ha ${ }^{-1}$ ), RDF + 3 spray of $3 \%$ Panchagavya at $15,25,35$ DAS $\left(\mathrm{T}_{2}\right)$, $\mathrm{RDF}+3$ spray of $4 \%$ Panchagavya at $15,25,35$ DAS $\left(\mathrm{T}_{3}\right), \quad \mathrm{RDF}+4$ spray of $3 \%$ Panchagavya at $15,25,35,45$ DAS $\left(\mathrm{T}_{4}\right), \mathrm{RDF}+4$ spray of $4 \%$ Panchagavya at $15,25,35,45$ DAS $\left(\mathrm{T}_{5}\right), 3$ spray of 3 $\%$ Panchagavya at $15,25,35$ DAS alone $\left(\mathrm{T}_{6}\right), 4$ spray of $3 \%$ Panchagavya at $15,25,35,45$ DAS alone $\left(\mathrm{T}_{7}\right)$, 3 spray of $4 \%$ Panchagavya at $15,25,35$ DAS alone $\left(\mathrm{T}_{8}\right), 4$ spray of $4 \%$ Panchagavya at $15,25,35,45$ DAS alone $\left(T_{9}\right), 75 \%$ RDF +3 spray of $3 \%$ Panchagavya at $15,25,35 \mathrm{DAS}\left(\mathrm{T}_{10}\right), 75 \% \mathrm{RDF}+3$ spray of $4 \%$ Panchagavya at $15,25,35 \mathrm{DAS}\left(\mathrm{T}_{11}\right), 75$ $\% \mathrm{RDF}+4$ spray of $3 \%$ Panchagavya at $15,25,35,45$ DAS $\left(\mathrm{T}_{12}\right), 75 \% \mathrm{RDF}+4$ spray of $4 \%$ Panchagavya at $15,25,35,45 \mathrm{DAS}\left(\mathrm{T}_{13}\right), \mathrm{RDF}+$ seed treatment $(3 \mathrm{ml}$ Panchagavya per $\mathrm{Kg})\left(\mathrm{T}_{14}\right)$.

Baby corn (COBC 1$)$ was used as the test variety for this experiment and seeds were obtained from the Tamil Nadu Agricultural University, Coimbatore, Tamil Nadu, India. The characteristic features of the test variety $\mathrm{COBC} 1$ are parentage of composite involving UMI 836 and UMI 836-1-2, duration 55-65 days (fresh cobs harvest) and flowering at 40 days after sowing. The seed rate required for raising the crop was $25 \mathrm{Kg} \mathrm{ha}^{-1}$ with the spacing of $45 \times 25 \mathrm{~cm}$. The crop was raised as per recommended package and practices (CPG, 2005). The fertilizer recommendation for baby corn is 150:60:40 Kg of N, $\mathrm{P}_{2} \mathrm{O}_{5}$ and $\mathrm{K}_{2} \mathrm{O}$ ha ${ }^{-1}$ respectively. Nitrogen was applied as urea $(46 \% \mathrm{~N})$, phosphorus as single superphosphate $\left(16 \% \mathrm{P}_{2} \mathrm{O}_{5}\right)$ and potassium as muriate of potash $\left(60 \% \mathrm{~K}_{2} \mathrm{O}\right)$. Half dose of $\mathrm{N}$, full dose of $\mathrm{P}_{2} \mathrm{O}_{5}$ and half dose of $\mathrm{K}_{2} \mathrm{O}$ were applied basal. The remaining doses of $\mathrm{N}$ and $\mathrm{K}_{2} \mathrm{O}$ were applied on 20 DAS.

Panchagavya preparation: Panchagavya was prepared by using the following ingredients obtained from the cow. Cow dung (5 kg), urine (3 litres), milk (2 litres), Curd (2 litres), Ghee (1 litre), Sugarcane juice (3 litres), Tender coconut water (3 litres) and Riped banana (1 $\mathrm{Kg}$ ). Cow dung was mixed with all other ingredients at once in the plastic container having a capacity of 20 litres, riped bananas were also added to facilitate quick fermentation. All the materials were put into a wide mounthed mud pot and kept open under shade. The contents were stirred for about 20 minutes, both in the morning and evening to facilitate aerobic microbial growth, aeration and to increase the storability period upto two months. After 10 days, the Panchagavya stock solution was ready for use. From the stock solution 3 per cent concentration was prepared according to the requirement (To get $3 \%$ concentration, 3 litres of Panchagavya were mixed with 100 litres of water). The spray solution@ 900 litres ha ${ }^{-1}$ was applied using hand sprayer with high pore size. The baby corn is harvested before the silking and detasseling done to avoid pollination.

Biometric observation: Five plants at random from each plot were selected and tagged for the purpose of recording growth attributes and yield of Baby corn. The plant height was measured from the base of the plant to the base of fully opened leaf and the average height of the plant was calculated and expressed in $\mathrm{cm}$. Leaf area index (LAI) is defined as the leaf area (assimilatory surface) per unit land area. It was calculated by using following formula suggested by Sestak et al. (1971). Leaf area per unit land area $=$ length of leaf $x$ width of leaf $\times 0.75 \times$ no. of leaves per plant $\times$ no. of plants per unit area

\section{$\mathrm{LAI}=\frac{\text { Total leaf area }\left(\mathrm{cm}^{2}\right)}{\text { Unit land area }\left(\mathrm{cm}^{2}\right)}$}

The girth of the stem from the sample plants of baby corn was measured at the point of maximum girth using thread and scale at harvest stage. The mean girth of the stem was computed and expressed in $\mathrm{cm}$. Harvested cobs from the net plot were weighed and green cob yield was recorded from individual plots and expressed in $t \mathrm{ha}^{-1}$. After final harvest of the cobs, green fodder from net plot was harvested and expressed as $t \mathrm{ha}^{-1}$.

Statistical analysis: Data were analyzed separately for both years. All the data on growth attributes and yield in the experiments were statistically analysed as suggested by Panse and Sukhatame (1978). The critical differences were worked out at $5 \%$ probability level.

\section{RESULTS AND DISCUSSION}

Growth parameters: The plant height was significantly increased with application of full dose of nutrients along with foliar spray of Panchagavya (Table 1). Among the treatments, application of $100 \%$ recommended dose of fertilizer along with four sprays of three per cent panchagavya at $15,25,35$ and 45 DAS recorded the tallest plants of $188.2,199.0 \mathrm{~cm}$ during first and second seasons, respectively. This treatment was onpar with $T_{2}$ and $T_{5}$. This might due to assimilation of nutrients through applied nutrient at required time leads to tallest plants compared to all other treatments. Application of $\mathrm{RDF}+$ panchagavya foliar spray increased the plant height due to increase in protein synthesis and cell 
Table 1. Effect of foliar spray of Panchagavya on the growth attributes of baby corn during two seasons.

\begin{tabular}{|c|c|c|c|c|c|c|c|c|}
\hline \multirow{2}{*}{ Treatments } & \multicolumn{2}{|c|}{$\begin{array}{l}\text { Plant height } \\
\quad(\mathrm{cm})\end{array}$} & \multicolumn{2}{|c|}{ LAI } & \multicolumn{2}{|c|}{ DMP $\left(\mathrm{kg} \mathrm{ha}^{-1}\right)$} & \multicolumn{2}{|c|}{$\begin{array}{l}\text { Stem girth } \\
\quad(\mathrm{cm})\end{array}$} \\
\hline & 2008 & 2009 & 2008 & 2009 & 2008 & 2009 & 2008 & 2009 \\
\hline Recommended dose of fertilizers (RDF) $\left(T_{1}\right)$ & 150.1 & 145.3 & 4.12 & 4.32 & 6200 & 6472 & 5.9 & 6.2 \\
\hline $\begin{array}{l}\text { RDF }+3 \text { sprays of } 3 \% \text { Panchagavya at } 15,25,35 \\
\text { DAS }\left(T_{2}\right)\end{array}$ & 174.9 & 193.1 & 4.44 & 4.61 & 7318 & 7657 & 7.2 & 7.5 \\
\hline $\begin{array}{l}\text { RDF }+3 \text { sprays of } 4 \% \text { Panchagavya at } 15,25,35 \\
\text { DAS }\left(T_{3}\right)\end{array}$ & 168.7 & 181.1 & 4.24 & 4.41 & 7039 & 7361 & 6.9 & 7.2 \\
\hline $\begin{array}{l}\text { RDF }+4 \text { sprays of } 3 \% \text { Panchagavya at } \\
15,25,35,45 \text { DAS }\left(T_{4}\right)\end{array}$ & 188.2 & 199.0 & 5.55 & 5.77 & 7457 & 7805 & 7.4 & 7.7 \\
\hline $\begin{array}{l}\text { RDF }+4 \text { spray of } 4 \% \text { Panchagavya at } 15,25,35,45 \\
\text { DAS }\left(T_{5}\right)\end{array}$ & 174.1 & 192.1 & 4.42 & 4.59 & 7312 & 7651 & 7.2 & 7.5 \\
\hline $\begin{array}{l}\text { Three sprays of } 3 \% \text { Panchagavya at } 15,25,35 \\
\text { DAS alone }\left(\mathrm{T}_{6}\right)\end{array}$ & 144.1 & 133.4 & 3.50 & 3.64 & 5921 & 6176 & 5.5 & 5.7 \\
\hline $\begin{array}{l}\text { Four sprays of } 3 \% \text { Panchagavya at } 15,25,35,45 \\
\text { DAS alone }\left(\mathrm{T}_{7}\right)\end{array}$ & 147.3 & 139.3 & 3.60 & 3.74 & 6060 & 6324 & 5.7 & 5.9 \\
\hline $\begin{array}{l}\text { Three spray of } 4 \% \text { Panchagavya at } 15,25,35 \\
\text { DAS alone }\left(T_{8}\right)\end{array}$ & 137.7 & 126.2 & 3.40 & 3.54 & 5776 & 6022 & 5.2 & 5.4 \\
\hline $\begin{array}{l}\text { Four sprays of } 4 \% \text { Panchagavya at } 15,25,35,45 \\
\text { DAS alone }\left(T_{9}\right)\end{array}$ & 138.0 & 127.4 & 3.39 & 3.53 & 5781 & 6028 & 5.3 & 5.5 \\
\hline $\begin{array}{l}75 \% \text { RDF }+3 \text { sprays of } 3 \% \text { Panchagavya at } 15, \\
25,35 \text { DAS }\left(T_{10}\right)\end{array}$ & 162.5 & 169.2 & 4.06 & 4.21 & 6759 & 7065 & 6.5 & 6.8 \\
\hline $\begin{array}{l}75 \% \text { RDF }+3 \text { sprays of } 4 \% \text { Panchagavya at } 15, \\
25,35 \text { DAS }\left(T_{11}\right)\end{array}$ & 156.5 & 157.2 & 3.89 & 4.04 & 6480 & 6768 & 6.2 & 6.5 \\
\hline $\begin{array}{l}75 \% \text { RDF }+4 \text { sprays of } 3 \% \text { Panchagavya at } 15, \\
25,35,45 \text { DAS }\left(T_{12}\right)\end{array}$ & 167.7 & 180.3 & 4.21 & 4.38 & 7034 & 7356 & 6.8 & 7.2 \\
\hline $\begin{array}{l}75 \% \text { RDF }+4 \text { sprays of } 4 \% \text { Panchagavya at } \\
15,25,35,45 \text { DAS }\left(T_{13}\right)\end{array}$ & 159.4 & 163.2 & 3.98 & 4.14 & 6619 & 6916 & 6.4 & 6.7 \\
\hline $\begin{array}{l}\text { RDF + seed treatment ( } 3 \mathrm{ml} \text { Panchagavya per kg) } \\
\left(\mathrm{T}_{14}\right)\end{array}$ & 153.3 & 151.3 & 3.79 & 3.85 & 6340 & 6620 & 6.0 & 6.3 \\
\hline SEd & 9.38 & 9.35 & 0.19 & 0.21 & 305 & 323 & 0.39 & 0.41 \\
\hline $\mathrm{CD}(\mathrm{P}=0.05)$ & 19.29 & 19.23 & 0.40 & 0.43 & 611 & 647 & 0.80 & 0.84 \\
\hline
\end{tabular}

Table 2. Effect of foliar spray of Panchagavya on the yield and fodder yield of baby corn during two seasons

\begin{tabular}{|c|c|c|c|c|}
\hline \multirow{2}{*}{ Treatments } & \multicolumn{2}{|c|}{ Green cob yield $(\mathrm{kg} / \mathrm{ha})$} & \multicolumn{2}{|c|}{ Fodder yield (t/ha) } \\
\hline & 2008 & 2009 & 2008 & 2009 \\
\hline Recommended dose of fertilizers (RDF) $\left(\mathrm{T}_{1}\right)$ & 6585 & 6618 & 22.52 & 23.64 \\
\hline $\mathrm{RDF}+3$ sprays of $3 \%$ Panchagavya at $15,25,35 \mathrm{DAS}\left(\mathrm{T}_{2}\right)$ & 7344 & 7381 & 30.76 & 32.29 \\
\hline $\mathrm{RDF}+3$ sprays of $4 \%$ Panchagavya at $15,25,35 \mathrm{DAS}\left(\mathrm{T}_{3}\right)$ & 7226 & 7262 & 28.70 & 30.12 \\
\hline $\mathrm{RDF}+4$ sprays of $3 \%$ Panchagavya at $15,25,35,45 \mathrm{DAS}\left(\mathrm{T}_{4}\right)$ & 7439 & 7476 & 31.78 & 33.37 \\
\hline $\mathrm{RDF}+4$ spray of $4 \%$ Panchagavya at $15,25,35,45 \mathrm{DAS}\left(\mathrm{T}_{5}\right)$ & 7318 & 7354 & 30.59 & 32.11 \\
\hline Three sprays of $3 \%$ Panchagavya at $15,25,35$ DAS alone $\left(T_{6}\right)$ & 6395 & 6427 & 20.46 & 21.48 \\
\hline Four sprays of $3 \%$ Panchagavya at $15,25,35,45$ DAS alone $\left(\mathrm{T}_{7}\right)$ & 6490 & 6523 & 21.49 & 22.56 \\
\hline Three spray of $4 \%$ Panchagavya at $15,25,35$ DAS alone $\left(\mathrm{T}_{8}\right)$ & 6238 & 6269 & 18.23 & 19.14 \\
\hline Four sprays of $4 \%$ Panchagavya at $15,25,35,45$ DAS alone $\left(T_{9}\right)$ & 6264 & 6295 & 18.40 & 19.32 \\
\hline $75 \%$ RDF +3 sprays of $3 \%$ Panchagavya at $15,25,35$ DAS $\left(\mathrm{T}_{10}\right)$ & 6964 & 6999 & 26.64 & 27.96 \\
\hline $75 \%$ RDF +3 sprays of $4 \%$ Panchagavya at $15,25,35$ DAS $\left(T_{11}\right)$ & 6775 & 6808 & 24.58 & 25.80 \\
\hline $75 \%$ RDF +4 sprays of $3 \%$ Panchagavya at $15,25,35,45$ DAS $\left(T_{12}\right)$ & 7200 & 7236 & 28.52 & 29.94 \\
\hline $75 \%$ RDF +4 sprays of $4 \%$ Panchagavya at $15,25,35,45$ DAS $\left(T_{13}\right)$ & 6869 & 6904 & 25.60 & 26.88 \\
\hline $\mathrm{RDF}+$ seed treatment ( $3 \mathrm{ml}$ Panchagavya per $\mathrm{kg})\left(\mathrm{T}_{14}\right)$ & 6680 & 6713 & 22.52 & 24.72 \\
\hline SEd & 418 & 421 & 1.55 & 1.63 \\
\hline $\mathrm{CD}(\mathrm{P}=0.05)$ & 861 & 865 & 3.19 & 3.36 \\
\hline
\end{tabular}

growth. This results of the present study in line with findings of Vijayalakshmi (2005) in Black gram. The highest leaf area index of 5.55 and 5.77 recorded dur- ing 2008 and 2009 respectively was recorded under $100 \%$ RDF +4 times spray of 3 per cent Panchagavya $\left(\mathrm{T}_{4}\right)$. Leaf expansion due to the presence of growth 
regulators such as IAA, GA, etc. in panchagavya might enhanced the Leaf Area Index which produced bigger leaves as experienced by Natarajan (2002) in vegetables and legumes. The least leaf area index of 3.39 and 3.53 was recorded under $T_{9}$ which was on par with $T_{8}$ during 2008 and 2009 respectively. The lower plant height and LAI due to inadequate nutrient supply during the crop growth stages (Rajendran, 1991). The dry matter production increased with age of the crop and reached peak at maturity (Table 1). Among the different treatments, the highest dry matter production was observed under $\mathrm{T}_{4}(100 \% \mathrm{RDF}$ of NPK + Panchagavya spray 4 times @ 3 per cent concentration) at both the stages of crop growth. This treatment was found to be significantly superior over the other treatments by recording the highest dry matter production of 7457 and $7805 \mathrm{Kg} \mathrm{ha}^{-1}$ at harvest during 2008 and 2009 , respectively. These results were in accordance with findings of Sridhar (2003). The least dry matter production of 5776 and $6022 \mathrm{Kg} \mathrm{ha}^{-1}$ at harvest during 2008 and 2009, respectively was recorded under panchagavya spray 3 times@4 per cent concentration alone $\left(\mathrm{T}_{8}\right)$. The stem girth of baby corn 7.4 and $7.7 \mathrm{~cm}$ during two seasons were recorded under the treatment $\mathrm{T}_{4}$ and this was in onpar with $\mathrm{T}_{2}, \mathrm{~T}_{5}$ and $\mathrm{T}_{12}$ respectively (Table 1).

Yield: A perusal of the data (Table 2) indicated that the yield of baby corn is significantly differed with the combined application of recommended dose of fertilizers along with foliar spray of Panchagavya. The highest yield of baby corn is observed in the $100 \%$ RDF + spray of $3 \%$ Panchagavya at $15,25,35$ and 45 DAS (7439 and $7476 \mathrm{Kg} \mathrm{ha}^{-1}$ ) in both the years, respectively. This might be due to adequate supply of nutrients at different growth stages of the crop as well as presence of growth regulators in Panchagavya contributing to higher cob yield (Sridhar et al., 2001 and Somasundaram et al., 2003). The yield of any crop plants depends on the assimilatory surface of the plant system. A sound source interms of plant height, LAI, Stem girth to support and hold the leaves are logically able to increase the dry matter and its distribution in different parts is important for determination of total yield of the rice crop (Krishnamurthy, 2012).

The least baby corn yield recorded under Panchagavya spray 3 times alone might be due to lack of adequate supply of nutrients (nitrogen, phosphorus and potassium) to the crop which inturn affected the growth of the crop ultimately reflecting on yield. Similar synergy was observed in vegetables and legumes by Natarajan (2002) with Panchagavya.

Fodder yield: Fodder yield is highest in the treatment, application of 100 per cent RDF along with four sprays of three per cent panchagavya at $15,25,35$ and 45 DAS with 31.78 and $33.37 \mathrm{t} \mathrm{ha}^{-1}$ which was followed by $\mathrm{T}_{3}, \mathrm{~T}_{2}$ and $\mathrm{T}_{5}$ (Table 2). The lowest fodder yield was recorded in the treatment four sprays of $4 \%$ Panchagavya at 15, 25, 35 and 45 DAS. This might be due to unavailable of nutrients during the critical crop growth stages. From this it may concluded that application of foliar nutrient itself cannot improve the baby corn production in addition to that integration of foliar and soil nutrient application recorded appreciable yield increase in baby corn (Zea mays L.) production (Rajanna et al., 2006).

\section{Conclusion}

Based on the study, the fresh baby corn yield was higher in application of 150:60:40 kg of N: $\mathrm{P}_{2} \mathrm{O}_{5}: \mathrm{K}_{2} \mathrm{O}$ along with four sprays of three per cent panchagavya at $15,25,35$ and 45 DAS recorded the highest growth and yield attributes of baby corn. It can be concluded that application of higher dose of inorganic nutrients (100\% RDF) along with $3 \%$ Panchagavya improved the growth attributes which ultimately reflected on the baby corn yield.

\section{ACKNOWLEDGEMENT}

The first author acknowledges Tamil Nadu State Council for Science and Technology (TNSCST), Autonomous body under Government of Tamil Nadu, Chennai - 25 for providing fellowship and Annamalai University for providing the experimental site and the laboratory facilities during M.Sc. (Agri) Agronomy degree programme.

\section{REFERENCES}

Auti, A. K., Wadice, S. C. and Pawar, V. S. (1999). Quality and nutrient removes of maize (Zea mays L.) as influenced by levels and source of fertilizer. Indian $J$. Agron., 454(1): 119-192.

CPG (2005). Crop production guide. published by Directorate of Agriculture, Chennai and Tamil Nadu Agricultural University, Coimbatore, India.

Krishnamurthy, R. (2012). Productivity and economics of rainfed rice as influenced by intergrated nutrient management. Madras Agric. J., 99 (4-6): 266-270.

Natarajan, K. (2002). Panchagavya - A Manual. Other India press, Mapusa, Goa, India, pp.33.

Panse V. G. and Sukhatame P. V. (1978). Statistical method for Agricultural workers. I.C.A.R. New Delhi, India pp. 145 .

Rai, P. K., Kumar, Y. and Sarraf, A. (2004). Baby corn: A potential crop. Intensive Agriculture, March - April : 3-9.

Rajanna, A. E., Ramachandrappa, B. K., Nanjappa, H. V., Soumya, T. M. (2006). Soil plant water status and yield of Baby corn (Zea mays L.) as influenced by fertility levels. Mysore J. Agric. Sci., 40(1): 74-82.

Rajendran, R. (1991). Response of greengram $\left(\mathrm{CO}_{4}\right)$ to soil and foliar nutrition. Madras Agric. J., 78(9-12): 453-455.

Sestak, Z., Catasky, J. and Arvis, P. G. (1971). Plant photosynthetic production: Manual of Methods (Ed. Junk N. V.), The Haque Publishers, pp. 72-78.

Somasundaram, E., Sankaran, N., Meena, S., Thiyagarajan, T. M., Chandragiri, K. and Pannerselvam. S. (2003). Response of greengram to varied level of panchagavya (organic nutrition) foliar spray. Madras Agric. J., 90: 169-172.

Sridhar, T. (2003). Effect of bio-regulators on Black night- 
shade (Solanum nigrum L.). M.Sc. Thesis. Tamil Nadu Agricultural University, Coimbatore, India.

Sridhar, S., Arumugasamy, S., Vijayalakshmi, K. and Balasubramanian, A.V. (2001). Vykshayurveda Ayurveda for plant - A user manual. Clarion 1:6.

Thavaprakaash, N., Velayudham, K. and Muthukumar, V. B. (2005). Effect of crop geometry, intercropping systems and integrated nutrient management practices on the productivity of baby corn (Zea mays L.) based intercropping systems. Res. J. Agrl. and Biol. Sci., 1 (4): 295-302.

Vijayalakshmi, K. (2005). Standardization of application time and dose of panchagavya in blackgram (Vigna mungo L.) under irrigated and rainfed conditions. M.Sc. (Ag.) Thesis, Tamil Nadu Agricultural University, Madurai. 